\title{
Invited review: Artisanal Mexican cheeses
}

\author{
Aarón F. González-Córdova, ${ }^{* 1}$ Carlos Yescas,† Ángel Martín Ortiz-Estrada, ${ }^{*}$ \\ María de los Ángeles De la Rosa-Alcaraz, * Adrián Hernández-Mendoza, * \\ and Belinda Vallejo-Cordoba* \\ *Laboratorio de Química y Biotecnología de Productos Lácteos, Coordinación de Tecnología de Alimentos de Origen Animal (CTAOA), \\ Centro de Investigación en Alimentación y Desarrollo, A.C. (CIAD) Carretera a La Victoria Km. 0.6, Apartado 1735, Hermosillo, \\ 83304 Sonora, Mexico \\ †Politics Department, The New School for Social Research, 6 East 16th Street, 7th Floor, New York, NY 10003
}

\section{ABSTRACT}

The objective of this review is to present an overview of some of the most commonly consumed artisanal Mexican cheeses, as well as those cheeses that show potential for a protected designation of origin. A description is given for each of these cheeses, including information on their distinguishing characteristics that makes some of them potential candidates for achieving a protected designation of origin status. This distinction could help to expand their frontiers and allow them to become better known and appreciated in other parts of the world. Due to the scarcity of scientific studies concerning artisanal Mexican cheeses, which would ultimately aid in the standardization of manufacturing processes and in the establishment of regulations related to their production, more than 40 varieties of artisanal cheese are in danger of disappearing. To preserve these cheeses, it is necessary to address this challenge by working jointly with government, artisanal cheesemaking organizations, industry, academics, and commercial partners on the implementation of strategies to protect and preserve their artisanal means of production. With sufficient information, official Mexican regulations could be established that would encompass and regulate the manufacture of Mexican artisanal cheeses. Finally, as many Mexican artisanal cheeses are produced from raw milk, more scientific studies are required to show the role of the lactic acid bacteria and their antagonistic effect on pathogenic microorganisms during aging following cheese making.

Key words: artisanal Mexican cheese, raw milk, pasteurized milk, protected designation of origin

Received July 11, 2015.

Accepted December 6, 2015.

${ }^{1}$ Corresponding author: aaronglz@ciad.mx

\section{INTRODUCTION}

Currently, cheesemaking is one of the most important industries in Mexico, and it uses approximately $25 \%$ of the total milk produced in the country (SIAP, 2013). It is believed that at least a similar percentage of milk is used by small-scale or artisan cheesemakers for the production of cheese, which is not as easily quantified. The importance of this industry is reflected in the estimation that around $70 \%$ of all Mexican cheese comes from small-scale productions (Cervantes-Escoto et al., 2008).

Among all the Mexican cheeses, quesos frescos, or fresh cheeses, are the most popular; almost $80 \%$ of the cheese consumed in Mexico falls within this category (Jiménez-Guzmán et al., 2009; Torres-Vitela et al., 2012). Although artisanal Mexican cheese is often produced from cow milk, several varieties, such as Panela, are produced from sheep and goat milks as well as from cow milk or from a mixture of these (RodriguezNogales and Vázquez, 2007; Cervantes-Escoto et al., 2008). Although fresh cheese is the most consumed variety in Mexico, there are several varieties of semiaged and aged cheeses such as Chihuahua and regional Cotija cheeses, respectively (Cervantes-Escoto et al., 2008; Cesin-Vargas et al., 2012). In Mexico, nearly 40 different varieties of cheese are recognized to date (Villegas de Gante and Cervantes-Escoto, 2011; Villegas de Gante et al., 2014). The most important varieties are Fresco, Panela, Oaxaca, and Chihuahua, due to their large production volumes, whether by traditional, semimechanized, or mechanized production (CervantesEscoto et al., 2008; SIAP, 2013).

In spite of the fact that the production of cheese is a daily activity in Mexico, the tradition of manufacturing cheese did not originate in the Americas but rather during its colonization by the Spanish and subsequently in the colonial territory of New Spain (currently Mexico). During this period, the Spanish brought the first herds of cattle, sheep, and goats. From the milk of these animals, the production of a wide variety of 
cheeses began. Subsequently, some of the production methods were modified, and many of these methods enriched with regional ingredients (e.g., chili peppers, annatto) by the local habitants, which gave rise to new varieties of cheese with unique sensory characteristics (Cervantes-Escoto et al., 2008; Hernández-Morales et al., 2010; Yescas, 2012; Villegas de Gante et al., 2014). Many of these varieties still exist today and form the basis of traditional Mexican cheesemaking (Villegas de Gante et al., 2014).

Because the majority of artisanal Mexican cheeses are produced from raw milk, they do not comply with Mexican regulations concerning food safety, which establish that all milk used for cheese production within the national territory must undergo pasteurization (SSA, 2010; Pomeón and Cervantes-Escoto, 2012). Therefore, cheeses that do not comply with such regulations with respect to the need for pasteurization are at risk of disappearing. This situation is unfortunate considering that Mexican artisanal cheeses represent more than just food. These cheese and their means of production are strongly linked to their place of origin and are a testimony to the history and culture of the communities that produce them (Licitra, 2010; Villegas de Gante, 2012).

Although several papers have described characteristics of specific artisanal Mexican cheeses, there is a need to present available knowledge of some of the most representative and popular varieties. Thus, the objective of this review is to present an overview of some of the most commonly consumed artisanal Mexican cheeses, as well as those cheeses that show potential for a protected designation of origin (PDO).

\section{THE CURRENT SCENARIO OF MEXICAN ARTISANAL CHEESES}

The main characteristics of the most representative Mexican artisanal cheese varieties are summarized in Table 1. Artisanal Mexican cheese production is carried out throughout Mexico, mainly from raw milk produced by pure breed or mixtures of cattle breeds. According to their moisture content, cheese types include soft, semi-hard, and hard. In terms of maturation, most are unripened and few may be semi-ripened or ripened (Table 1).

Despite their importance in Mexico, artisanal cheeses are undergoing a crisis; for example, Oaxaca cheese was once exclusively produced using artisanal methods in the state of Oaxaca. However, today its production is mostly large-scale and mechanized and carried out in different regions of Mexico, therefore losing its regional character and putting traditional artisanal means of production at risk of disappearing. This situation is not exclusive to Oaxaca cheese: Chihuahua cheese, Panela, and fresh cheeses are facing the same problem of losing their regional character (Torres-Llanez et al., 2006; Tunick et al., 2007; Cervantes-Escoto et al., 2008; Torres-Vitela et al., 2012; Villanueva-Carvajal et al., 2012; Yescas, 2012; Villegas de Gante, 2012).

Several varieties of artisanal Mexican cheese such as Barca, Jobo, Astillero, and Ixtapan have completely disappeared. Other varieties such as Crema de Chiapas, Bola de Ocosingo (Chiapas), Guaje, Cincho, Hoja, Rueda, and Poro de Balancan (Tabasco) are produced and consumed in specific regions of the country, thus positioning themselves as regional products that are not well known outside of their areas of origin in Mexico. In fact, an additional difficulty surrounds the classification of these cheeses, because several distinct varieties may hold the same name but be different in taste, texture, and form, or they may have distinct names and in reality be the same kind of cheese (Cervantes-Escoto et al., 2008).

Another issue surrounding artisanal Mexican cheeses is that they may be considered unsafe for consumption, as several studies carried out on "Mexican style" cheeses have associated them with different foodborne illness outbreaks (Linnan et al., 1988; MacDonald et al., 2005; Harris et al., 2007; Jackson et al., 2011). However, perhaps the greatest difficulty surrounding artisanal Mexican cheeses is the scarcity of available information, as only a few of these cheeses have been systematically characterized.

In general, previous publications of artisanal Mexican cheeses have outlined their history, manufacturing process, and main characteristics (Cervantes-Escoto et al., 2008; Villegas de Gante et al., 2014). Some specific studies have focused on evaluating their sanitary quality (Solano-López and Hernández-Sánchez, 2000; Moreno-Enriquez et al., 2007; Torres-Vitela et al., 2012; Soto-Beltran et al., 2013; Alejo-Martínez et al., 2015) or physicochemical characteristics (De Oca-Flores et al., 2009; Hernández-Morales et al., 2010; Caro et al., 2014; Gamboa Alvarado et al., 2013). Their sensory characteristics (Van Hekken et al., 2006; Paul et al., 2012; Villanueva-Carvajal et al., 2012; Alejo-Martínez et al., 2015), texture, and rheological (or elastic) properties (Tunick et al., 2007; Van Hekken et al., 2008; Guerra-Martínez et al., 2012; Morales-Celaya et al., 2012; Solís-Méndez et al., 2013) have also been evaluated. Although still lacking in information, the microbiota associated with artisanal Mexican cheeses has been studied and characterized (Torres-Llanez et al., 2006; Flores-Magallón et al., 2011; Renye et al., 2011; Saxer et al., 2013; Aldrete-Tapia et al., 2014; Alejo-Martínez et al., 2015), including the role of the different microbial groups present in these cheeses and their effect on food 


\begin{tabular}{|c|c|c|c|c|c|}
\hline Name of cheese & Production area & $\begin{array}{l}\text { Type of } \\
\text { milk used }\end{array}$ & Origin of milk & $\begin{array}{l}\text { Production } \\
\text { level }\end{array}$ & Type \\
\hline Adobera & $\begin{array}{l}\text { Jalisco, Guanajuato, } \\
\text { Aguascalientes, } \\
\text { Zacatecas }\end{array}$ & Raw & Cow, Holstein & Artisanal & $\begin{array}{l}\text { Soft, pressed, milled, } \\
\text { fresh or slightly } \\
\text { ripened }\end{array}$ \\
\hline Asadero & $\begin{array}{l}\text { Durango, Chihuahua, } \\
\text { Coahuila, } \\
\text { Aguascalientes, } \\
\text { Jalisco, Guanajuato }\end{array}$ & Raw & Cow, Holstein & $\begin{array}{l}\text { Artisanal, } \\
\text { Industrial }\end{array}$ & Filata, unripened \\
\hline Bola de Ocosingo & $\begin{array}{l}\text { Ocosingo and } \\
\text { surrounding } \\
\text { municipalities } \\
\text { (Chiapas) }\end{array}$ & Raw & $\begin{array}{l}\text { Cow, Zebu- } \\
\text { Brown Swiss }\end{array}$ & Artisanal & $\begin{array}{l}\text { Outer hard rind, soft } \\
\text { paste inside, semi- } \\
\text { ripened }\end{array}$ \\
\hline Chihuahua & Chihuahua & $\begin{array}{l}\text { Raw, } \\
\text { pasteurized }\end{array}$ & Cow, Holstein & $\begin{array}{l}\text { Artisanal, } \\
\text { Industrial }\end{array}$ & $\begin{array}{l}\text { Semi-hard, pressed, } \\
\text { cheddarized, lightly } \\
\text { cooked or uncooked, } \\
\text { semi-ripened }\end{array}$ \\
\hline Cotija type & $\begin{array}{l}\text { Jalisco, Michoacán, } \\
\text { Veracruz, Chiapas }\end{array}$ & $\begin{array}{l}\text { Raw, } \\
\text { pasteurized }\end{array}$ & $\begin{array}{l}\text { Cow, Holstein, } \\
\text { Holstein-Creole, } \\
\text { Zebu-Brown } \\
\text { Swiss, Holstein- } \\
\text { Zebu }\end{array}$ & $\begin{array}{l}\text { Artisanal, } \\
\text { Industrial }\end{array}$ & $\begin{array}{l}\text { Hard, pressed, } \\
\text { uncooked, ripened }\end{array}$ \\
\hline Crema de Chiapas & Chiapas, Tabasco & Raw & $\begin{array}{l}\text { Cow, Zebu- } \\
\text { Brown Swiss }\end{array}$ & Artisanal & $\begin{array}{l}\text { Soft, pressed, lightly } \\
\text { ripened }\end{array}$ \\
\hline
\end{tabular}

Shape an

Reference from $500 \mathrm{~g}$ to

from 500

Cylindrical-flat or rectangular prism; from 5 to $10 \mathrm{~kg}$

Tunick et al. 2007; Van Hekken et al., 2007;

Large format, cylindrical; from 20 to $30 \mathrm{~kg}$

et al., 2013

Cervantes-Escoto

et al., 2008

Cow, Zebu-

ripened

Small pieces

prismatic-

Cervantes-Escoto rectangular and cylindrical flat; from 250 to

\begin{tabular}{|c|c|}
\hline De Cincho & Morelos, Guerrero \\
\hline De Epazote & $\begin{array}{l}\text { Hidalgo, Puebla, } \\
\text { Tlaxcala, State of } \\
\text { Mexico }\end{array}$ \\
\hline De Hoja & Veracruz \\
\hline De Morral & $\begin{array}{l}\text { Hidalgo, Puebla, } \\
\text { State of Mexico, } \\
\text { Jalisco }\end{array}$ \\
\hline De Rueda & Veracruz \\
\hline
\end{tabular}

Raw

Cow, Zebu-

Brown Swis

Cow, Holstein

Creole

Artisanal

Semi-hard, pressed,

$1,000 \mathrm{~g}$

Pasteurized

Industrial

Raw

Cow, Zebu-

Brown Swiss

Pasteurized Cow, Holstein

Artisanal

Industrial

Raw

Cow, goat (or

mixture of both)

Artisanal

Fresco (Molido, de Aro, Ranchero)

Guaje (de Bola)

Practically
throughout México

Raw

pasteurized

San Luis Potos
Raw

\section{Cow, goat}

Cow, ZebuBrown Swiss
Artisanal Industrial

Artisanal ripened

Semi-hard

Soft, autopressed, unripened

Semi-hard, pressed, semi-ripened

Firm, chopping, lightly pressed

Soft, fresh,

unpressed, unripened

Filata, unripened
Cylindrical; >2 $\mathrm{g}$

Cylindrical; from $500 \mathrm{~g}$ to $2 \mathrm{~kg}$

Small, cylindrical; around $250 \mathrm{~g}$

Pillow shape; from 2 to $5 \mathrm{~kg}$

Cylindrical, flat, from $10.5 \mathrm{~cm}$ of diameter, $2.4 \mathrm{~cm}$ high. Other sizes; a few grams

Cylindrical; from

$250 \mathrm{~g}$ to $>1 \mathrm{~kg}$

Small guaje; from $200 \mathrm{~g}$ to $>1 \mathrm{~kg}$ et al., 2008;

et al., 2009

Cervantes-Escoto et al., 2008

Cervantes-Escoto et al., 2008

Cervantes-Escoto et al., 2008 Cervantes-Escoto et al., 2008

Cervantes-Escoto et al., 2008

Torres-Llanez et al., 2006; Cervantes-Escoto et al., 2008 Cervantes-Escoto et al., 2008 
Table 1 (Conitnued). Principal characteristics of most representative Mexican artisanal cheeses

\begin{tabular}{|c|c|c|c|c|c|c|c|}
\hline Name of cheese & Production area & $\begin{array}{l}\text { Type of } \\
\text { milk used }\end{array}$ & Origin of milk & $\begin{array}{l}\text { Production } \\
\text { level }\end{array}$ & Type & $\begin{array}{l}\text { Shape and } \\
\text { weight }\end{array}$ & Reference \\
\hline Mexican Manchego type & Queretaro & Pasteurized & Cow, Holstein & Industrial & $\begin{array}{l}\text { Semi-hard, pressed, } \\
\text { uncooked ripened }\end{array}$ & $\begin{array}{l}\text { Cylindrical-flat } \\
\text { and rectangular } \\
\text { prism; from } 1 \text { to } \\
5 \mathrm{~kg}\end{array}$ & $\begin{array}{l}\text { Lobato-Calleros et } \\
\text { al., } 2006\end{array}$ \\
\hline $\begin{array}{l}\text { Oaxaca (de Bola, Quesillo, } \\
\text { de Hebra) }\end{array}$ & $\begin{array}{l}\text { Practically } \\
\text { throughout México }\end{array}$ & $\begin{array}{l}\text { Raw, } \\
\text { pasteurized }\end{array}$ & $\begin{array}{l}\text { Cow, Holstein, } \\
\text { Zebu-Brown } \\
\text { Swiss }\end{array}$ & $\begin{array}{l}\text { Artisanal, } \\
\text { Industrial }\end{array}$ & Filata, unripened & $\begin{array}{l}\text { Balls or hanks; } \\
\text { from } 25 \mathrm{~g} \text { to }>1 \\
\mathrm{~kg}\end{array}$ & $\begin{array}{l}\text { Cervantes-Escoto } \\
\text { et al., 2008; De } \\
\text { Oca-Flores et al., } \\
\text { 2009; Villanueva- } \\
\text { Carvajal et al., } \\
2012\end{array}$ \\
\hline Region de Origen Cotija & $\begin{array}{l}\text { Sierra de Jalmich } \\
\text { (Jalisco and } \\
\text { Michoacán) }\end{array}$ & Raw & $\begin{array}{l}\text { Cow, Zebu- } \\
\text { Brown Swiss }\end{array}$ & Artisanal & $\begin{array}{l}\text { Semi-hard, hard, } \\
\text { pressed, ripened }\end{array}$ & $\begin{array}{l}\text { Large format, } \\
\text { cylindrical; about } \\
20 \mathrm{~kg}\end{array}$ & $\begin{array}{l}\text { Chombo-Morales, } \\
\text { 2008; Flores- } \\
\text { Magallón et al., } \\
2011\end{array}$ \\
\hline Panela & $\begin{array}{l}\text { Practically } \\
\text { throughout México }\end{array}$ & $\begin{array}{l}\text { Raw, } \\
\text { pasteurized }\end{array}$ & Holstein & $\begin{array}{l}\text { Artisanal, } \\
\text { Industrial }\end{array}$ & $\begin{array}{l}\text { Soft, fresh, } \\
\text { unpressed, unripened }\end{array}$ & $\begin{array}{l}\text { Inverted conical; } \\
\text { from } 0.5 \text { to } \sim 2 \mathrm{~kg}\end{array}$ & $\begin{array}{l}\text { Cervantes-Escoto } \\
\text { et al., 2008; } \\
\text { Torres-Vitela et } \\
\text { al., } 2012\end{array}$ \\
\hline Poro de Balancán & $\begin{array}{l}\text { Balancán and other } \\
\text { townships in zone of } \\
\text { rivers (Tabasco) }\end{array}$ & Raw & $\begin{array}{l}\text { Cow, Zebu- } \\
\text { Brown Swiss }\end{array}$ & Artisanal & $\begin{array}{l}\text { Soft, pressed, lightly } \\
\text { ripened }\end{array}$ & $\begin{array}{l}\text { Small pieces } \\
\text { prismatic } \\
\text { rectangular- } \\
\text { plane; from } 250 \\
\text { to } 1,000 \mathrm{~g}\end{array}$ & $\begin{array}{l}\text { Cervantes-Escoto } \\
\text { et al., 2008; } \\
\text { Aldrete Tapia et } \\
\text { al., 2014; Alejo- } \\
\text { Martínez et al., } \\
2015\end{array}$ \\
\hline Sierra & $\begin{array}{l}\text { Jalisco, Guanajuato, } \\
\text { Michoacán }\end{array}$ & Raw & Cow, Holstein & Industrial & Semi-hard, pressed & $\begin{array}{l}\text { Cylindrical; }>2 \\
\mathrm{~kg}\end{array}$ & $\begin{array}{l}\text { Cervantes-Escoto } \\
\text { et al., } 2008\end{array}$ \\
\hline Sopero & Tabasco & Raw & $\begin{array}{l}\text { Cow, Zebu- } \\
\text { Brown Swiss }\end{array}$ & Artisanal & $\begin{array}{l}\text { Soft, chopping, } \\
\text { lightly pressed }\end{array}$ & $\begin{array}{l}\text { Prismatic- } \\
\text { rectangular, } \\
\text { cylindrical of } 500 \\
\mathrm{~g} \text { to } 1 \mathrm{~kg}\end{array}$ & $\begin{array}{l}\text { Cervantes-Escoto } \\
\text { et al., } 2008\end{array}$ \\
\hline Tetilla & Nayarit & Raw & $\begin{array}{l}\text { Cow, Zebu- } \\
\text { Brown Swiss }\end{array}$ & Artisanal & $\begin{array}{l}\text { Semi-hard, fresh, } \\
\text { lightly ripened or } \\
\text { ripened }\end{array}$ & $\begin{array}{l}\text { Conical form } \\
\text { with } 10-12 \mathrm{~cm} \\
\text { of base; close to } \\
1 \mathrm{~kg}\end{array}$ & $\begin{array}{l}\text { Cervantes-Escoto } \\
\text { et al., } 2008\end{array}$ \\
\hline Trenzado & Veracruz, Oaxaca & Raw & $\begin{array}{l}\text { Cow, Zebu- } \\
\text { Brown Swiss }\end{array}$ & Artisanal & $\begin{array}{l}\text { Filata, firm, } \\
\text { unripened }\end{array}$ & Braiding & $\begin{array}{l}\text { Cervantes-Escoto } \\
\text { et al., } 2008\end{array}$ \\
\hline
\end{tabular}


safety, sensory characteristics, and shelf life. Although there are several artisanal Mexican cheese varieties, few have been fully characterized (Table 1).

The fact that scientific studies on artisanal Mexican cheeses are scarce, the lack of standardization in manufacturing processes, and the deficient organizational capability on behalf of cheese producers have led to lack of specific defined standards. For all of these reasons, none of these cheeses have been included within a PDO classification system. However, the panorama has begun to change, as some organizations specializing in artisanal cheese, with the support of research centers and Mexican universities, have obtained a collective mark for regional Cotija cheeses (Poméon, 2007), Bola de Ocosingo, Poro de Balancan, and Crema de Chiapas. Although the distinction of a collective mark is not the same as PDO, it represents an official protection and competitive advantage for the producers of these cheeses, so that consumers may differentiate between genuine artisanal cheese and its imitations. In addition, the collective mark serves to guarantee product quality and a fair price for cheesemakers. This demonstrates the need for groups of experts that support cheesemaking organizations to unite and carry out studies on the different varieties of Mexican artisanal cheeses with the goal of obtaining information that would help to protect and to regulate their production in agreement with Mexican regulations surrounding food safety. This would offer protection to Mexican traditional cheeses so that they would not lose their artisanal character and it would guarantee the quality and safety of the product.

\section{MAIN MEXICAN ARTISANAL CHEESES}

\section{Queso Fresco}

Queso Fresco (QF) is the most popular and most consumed cheese in Mexico and Latin America and comes in several varieties, including Aro, Molido, and Ranchero (Torres-Llanez et al., 2006; Cervantes-Escoto et al., 2008). This type of cheese is produced not only throughout Mexico but also in other regions of the continent (Cervantes-Escoto et al., 2008). In recent years, the popularity of QF has increased among North American consumers; in 2012, more than 224 million pounds of Hispanic style cheeses were produced in the United States, and of those, QF was the most consumed (Van Hekken et al., 2012; NASS, 2013).

As QF is produced on a mass scale, the manufacturing process and the ingredients used for its production are similar in many regions and countries of the American continent. However, due to small variations in the manufacturing process and the ingredients utilized, the physicochemical composition of QF differs according to the producing region (Van Hekken and Farkye, 2003).

On the other hand, artisanal Queso Fresco (Figure 1) may be distinguished in Mexico by the lack of standardization during its manufacturing process. In general, its physicochemical composition is characterized by a moisture content ranging from 46 to $67 \%$ and by 14 to $29 \%$ fat, 15 to $21 \%$ protein, and 1 to $3 \%$ salt. Artisanal QF may be produced with whole, partially skimmed, or skim milk and has a short shelf life. It is formed in a cylindrical shape, and its weight varies widely, from $200 \mathrm{~g}$ to $1 \mathrm{~kg}$. The texture is soft and creamy, and its color is bright white. The cheese crumbles easily, and its flavor is lightly reminiscent of fresh, salty milk (Figure 1; Torres and Chandan, 1981; Van Hekken and Farkye, 2003; Torres-Llanez et al., 2006).

In general, artisanal QF is produced from raw milk using traditional manufacturing methods and on a small scale, often with the use of a commercial curdling agent and without the addition of a starter culture. Due to its production attributes, a large diversity of lactic acid bacteria (LAB) are present throughout the cheesemaking process, which acidify the milk and give rise to the typical characteristics of this cheese (Higuera-Ciapara, 1986; Torres-Llanez et al., 2006).

\section{Queso Panela}

Queso Panela (QP) is produced in practically all regions of Mexico and is similar in characteristic to Greek feta cheese. It is soft and white in color, has hints of fresh, sweet milk flavor, and takes the form of the basket in which it is pressed (Figure 2). Although mainly produced from pasteurized cow milk, QP may be occasionally produced from sheep or goat milk or a mixture of these milks, and either whole or partially

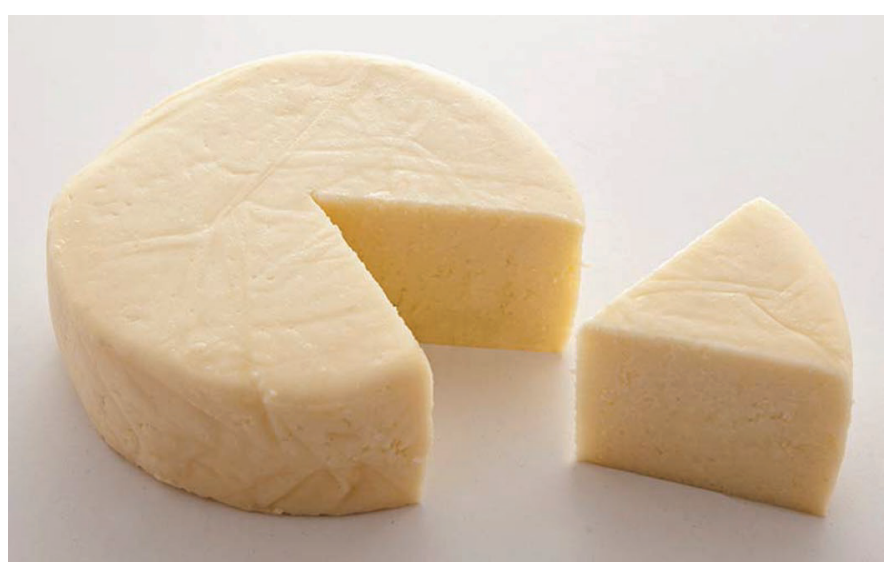

Figure 1. Artisanal Mexican queso Fresco. 
skim milk can be used (Cervantes-Escoto et al., 2008; Jiménez-Guzmán et al., 2009). As QP is generally produced with pasteurized milk, the type of facility where it is made generally has a certain level of automation (semi-automatic or automatic; Cervantes-Escoto et al., 2008). However, this cheese is also produced in smaller proportions from raw milk by artisanal cheesemakers (Figure 2).

Queso Panela is widely popular in Mexico, where in 2012 alone, nearly 20 million pounds were produced, making it one of the cheeses with highest production volumes in Mexico (SIAP, 2013). Its popularity likely resides in the fact that it is considered to be "healthy" by consumers because of its low fat content (LobatoCalleros et al., 2006). However, due to its moisture content (53-58\%), it is very perishable (Saxer et al., 2013). It is marketed in portions weighing from approximately 0.5 to $2 \mathrm{~kg}$ (Cervantes-Escoto et al., 2008).

The process of producing QP is relatively simple and similar to that of nearly all Mexican quesos frescos. One of the distinguishing characteristics of this cheese is its form, as it is molded in wicker, palm, reed, or plastic baskets (Cervantes-Escoto et al., 2008).

Recently, Saxer et al. (2013) characterized the microbiota of several Mexican cheeses and found that LAB from the Lactococcus and Enterococcus genera and the yeast Candida guilliermondii are the most important bacterial and fungal populations for QP cheese, which is interesting, considering that a starter culture is not used for the production of QP. This implies that bacterial and fungal populations are present in the processing environment and very likely contribute to the development of the taste, smell, and texture of QP.

\section{Queso Oaxaca}

Queso Oaxaca (QO), also known as queso de Hebra, de Bola, or Quesillo, is a stretched, pasta filata cheese that is widely popular and one of the most consumed dairy products in Mexico. Its name is linked to the state of Oaxaca, where it likely originated (De OcaFlores et al., 2009; Domínguez-López et al., 2011). However, it is currently produced in several distinct regions of Mexico at an artisanal scale as well as at a larger, industrial production level, from either raw or pasteurized milk from both multi-purpose and specialized cattle livestock (Zebu-Brown Swiss, Zebu-Holstein; Cervantes-Escoto et al., 2008).

Queso Oaxaca is considered a fresh cheese and may contain a moisture content of up to $50 \%$ (CervantesEscoto et al., 2008; Villegas de Gante et al., 2014). During the manufacturing process for this cheese, the curd is acidified until reaching a $\mathrm{pH}$ level of 5.3 and then kneaded in hot water and stretched. Afterward,

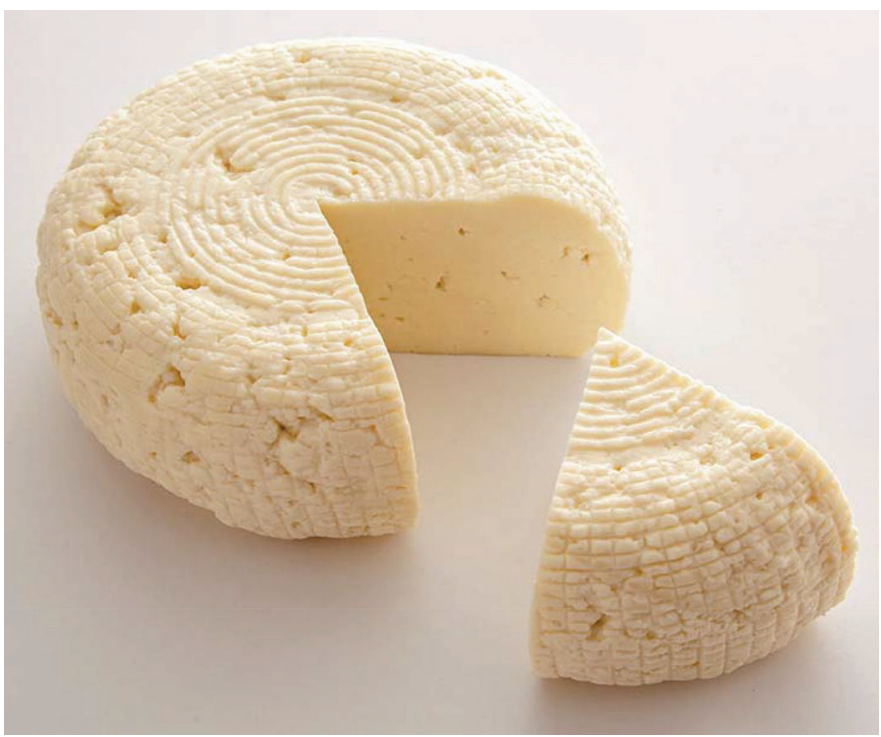

Figure 2. Artisanal Mexican queso Panela.

thin strips are formed from the forming cheese, which are cooled in salted water and then cut into segments (Figure 3). Subsequently, the segments are braided into the typical ball or knot form, which can weigh from a few grams to several kilograms (Cervantes-Escoto et al., 2008; Villegas de Gante et al., 2014; Caro et al., 2011).

The artisanal production process of genuine QO is similar to that of Mozzarella cheese (Yescas, 2012), and it requires specific knowledge of several critical steps during the manufacturing process that need to be rec-

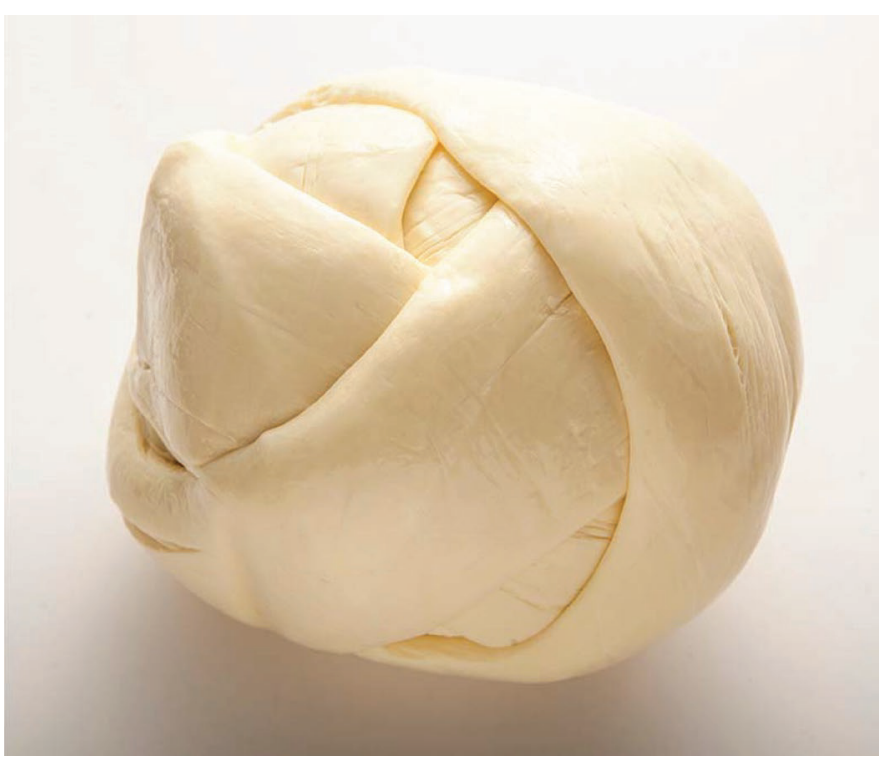

Figure 3. Artisanal Mexican queso Oaxaca. 
ognized by the artisan, such as the necessary acidity to obtain a stretchable cheese or the quantity of salt that should be added. These cheesemaking abilities are essential to minimizing variability between different production batches and their sensory and structural characteristics (Morales-Celaya et al., 2012). Due to its production from raw milk, its flavor notes are milky, buttery, acidic, and fermented (Villanueva-Carvajal et al., 2012; Yescas, 2012). The combination of these factors make $\mathrm{QO}$ an exquisite cheese for the taste palate, and it is unique among traditional Mexican cheeses due to its delicate manufacturing process.

\section{Queso Chihuahua}

Queso Chihuahua (QCH), also known as Mennonite or Chester cheese, is a traditional cheese from the state of Chihuahua. This cheese is marketed in blocks that range from $250 \mathrm{~g}$ to $10 \mathrm{~kg}$ (Figure 4) and is semi-hard, pressed, easy to melt, and slightly matured for 3 to 6 wk, with sour, bitter, and salty notes (Van Hekken et al., 2006; Cervantes-Escoto et al., 2008). It is mainly produced from pasteurized cow milk, either whole or with a standardized fat content (Van Hekken et al., 2007; Cervantes-Escoto et al., 2008). The origin of this cheese is linked to the Mennonite communities that migrated from Canada to Mexico in the 1920s and settled in the state of Chihuahua (Cervantes-Escoto et al., 2008). Currently, QCH is also produced in regions where Mennonite settlements do not exist, which has resulted in the existence of many varieties of QCH that, although considered genuine, possess their own unique set of characteristics.

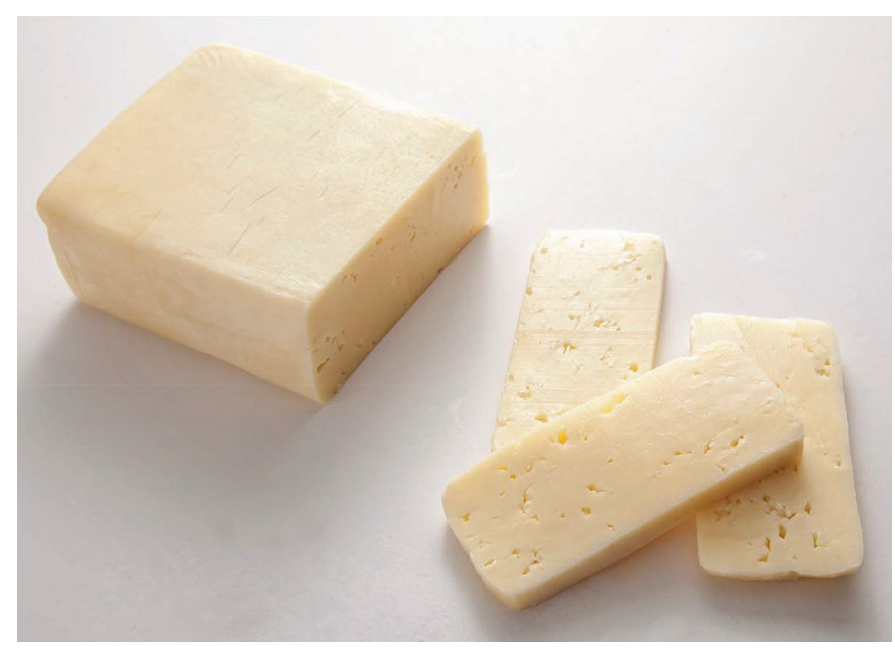

Figure 4. Artisanal Mexican queso Chihuahua.
Queso Chihuahua arose from the production of Cheddar cheese by Mennonite communities. Upon attempting to produce Cheddar cheese by Mennonite communities in Mexico, QCH was manufactured. The most critical phase during the manufacture of $\mathrm{QCH}$ is during its cheddarization. During this step, the Dornic acidity is maintained at 32 to 38 degrees Dornic $\left({ }^{\circ} \mathrm{D}\right)$, which is crucial to the development of the unique characteristics of this cheese.

Recently, in an attempt to standardize the manufacturing process for $\mathrm{QCH}$, governmental authorities, along with support from academic, industrial, and cheesemaking organizations, established and approved the Mexican regulation NMX-F-738-COFOCALEC-2011, which declared that milk destined for the production of $\mathrm{QC}$ should undergo a pasteurization process (COFOCALEC, 2011b). Independently of this requirement, QCH continues to be produced from raw milk by artisanal cheesemakers, resulting in a cheese that is softer in texture and that has a more intense flavor than if it were produced with pasteurized milk (Van Hekken et al., 2006). Some of the LAB of raw milk that influence the taste and texture of this cheese have been identified and proposed as potential starter cultures for standardized production of this cheese (Renye et al., 2011; Ortiz-Estrada, 2014). The most abundant identified microorganisms in QC were those of the genera Lactococcus, Lactobacillus, Streptococcus, Leuconostoc, and Enterococcus, as determined by DNA sequencing following denaturing gradient gel electrophoresis (DGGE) of PCR products obtained from DNA extracted from samples (Ortiz-Estrada, 2014).

\section{Queso Bola de Ocosingo}

Queso Bola de Ocosingo (QBO) is unusual compared with other artisanal Mexican cheeses because it is formed from 2 cheeses, one bundled inside another. Its production process is peculiar and has been passed from generation to generation since the arrival of cattle livestock in the region. Queso Bola de Ocosingo is formed into a hard, spherical shape (Figure 5) and weighs approximately $1 \mathrm{~kg}$ (Cervantes-Escoto et al., 2008).

Although the Italian cheese Cacciocavallo is similar in shape and type, it is thought that QBO was originally inspired by the Dutch cheese Edam. Queso Bola de Ocosingo was the first cheese to be collectively branded in Mexico, and a wider protection, such as a PDO classification, has recently been sought for this cheese. Its distinction as a collective mark is based upon its artisanal production that uses raw milk exclusively from Zebu-Brown Swiss cattle in Ocosingo, an 


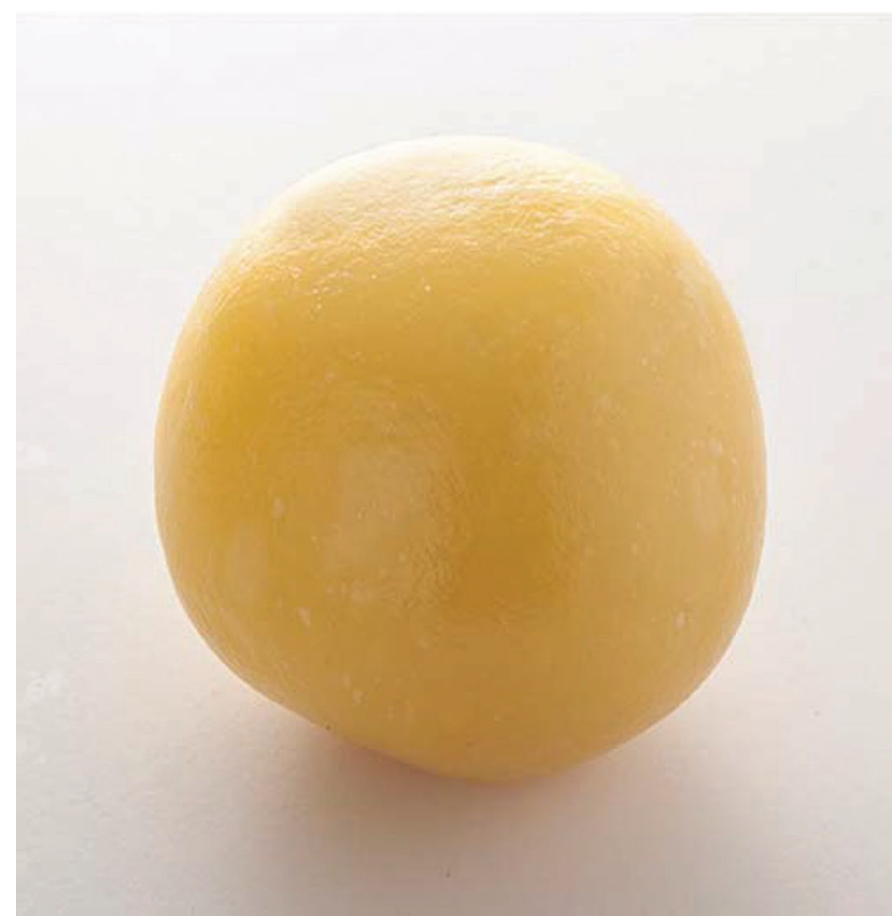

Figure 5. Artisanal Mexican queso Bola de Ocosingo.

area located in the northeastern region of the Mexican state of Chiapas (Yescas, 2009).

The production of QBO can be divided into 2 phases: (1) the acidification of the milk and a use of a mix of coagulants to solidify the cheese rennet and acidic whey obtained from the previous day, and (2) the preparation of an outer lining from skim milk. The production of QBO starts with the curdling of the milk for $24 \mathrm{~h}$, after which it is placed in a sack or cotton cloth to drain the whey. Afterward, a small amount of salt is added, and the curds are placed on a new cloth for $8 \mathrm{~d}$ until the cheese matures. During this ripening process, the cloth is changed every $3 \mathrm{~d}$ and the curds are kneaded. Finally, the cheese is compacted by hand into the shape of a ball and covered with 2 successive layers of stringy, curling milk produced from skim milk, which is rich is casein and which, upon cooling and airing out, hardens and functions as a protective packaging (CervantesEscoto et al., 2008). Inside, the cheese is bright yellow in color, with a creamy texture and a milky, salty, and fresh taste (Yescas, 2009).

\section{Queso Poro de Balancan}

Queso Poro de Balancan (QPB) is a regional cheese produced only by artisanal cheesemakers located in the municipalities of Balancan, Tenosique, Jonuta, and Emiliano Zapata (river zone) in Tabasco, Mexico. The beginnings of its artisanal production date back more than 50 yr. This cheese was recently protected as a collective mark. Currently, different characterization studies are being carried out to analyze the microbiota of QPB during the different stages of its manufacturing process, with the goal of understanding its composition and the possibility of scientifically standardizing its production as part of a strategy to achieve a wider protection as a PDO product (de la Rosa Alcaráz, 2013, 2015; Aldrete-Tapia et al., 2014).

Queso Poro de Balancan is a fresh cheese, although it can involuntarily mature in up to 4 wk if its distribution is slow. It is marketed in small, rectangular pieces (Figure 6) and covered with wax and yellow cellophane. Queso Poro de Balancan is demineralized and crumbly because the curds and forming cheese are layered on top of each other during the molding process. Therefore, when QPB is cut, it appears to be separated in layers and on occasion has small holes ("poros" or pores), resulting in its name. Its porous appearance is also a common effect of the typically present microbiota (Cervantes-Escoto et al., 2008; de la Rosa-Alcaráz, 2013, 2015).

For the manufacture of QPB, only raw milk from the Zebu-Brown Swiss variety of cattle is used. Its specific production processes are crucial for achieving its characteristic acidity and taste. As part of the first step in the process, to set the milk, a mix of rennet and acidic whey (obtained by fermentation of the whey from the previous day's production) is used. Afterward, the cheese is cut in blocks, left to rest for 2 to $4 \mathrm{~h}$, and then immediately placed in wooden molds to drain the whey for $24 \mathrm{~h}$. After $24 \mathrm{~h}$, the cheese is transferred to small molds and pressed in a rustic wooden press for $2 \mathrm{~d}$.

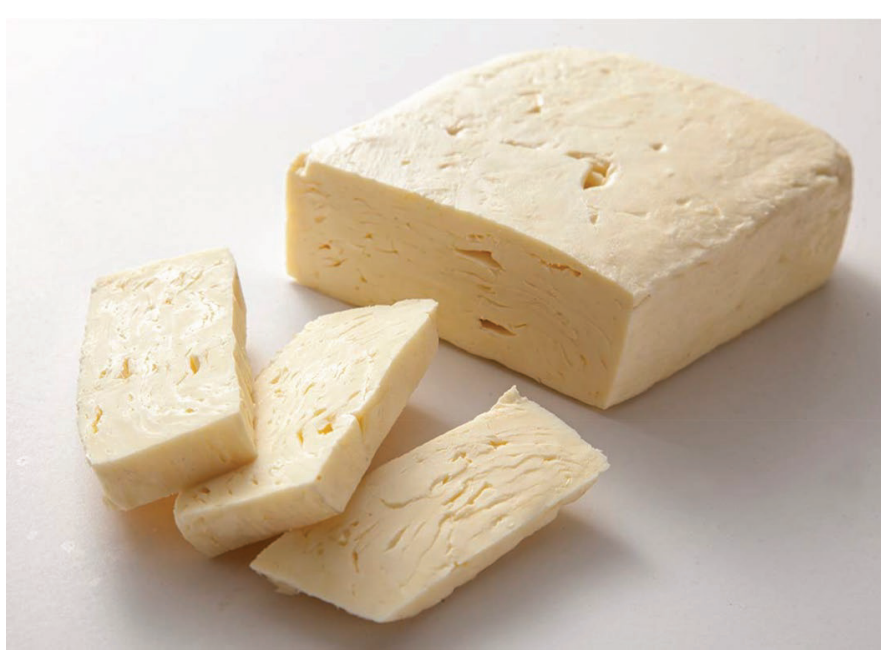

Figure 6. Artisanal Mexican queso Poro de Balancan. 
Once pressed, the cheese is partially matured on wooden shelves, called "roperos" in Spanish ("wardrobes") for 3 or $4 \mathrm{~d}$. During this time, the rind of the cheese receives an additional application of salt. Finally, the cheese is covered with wax and wrapped in cellophane.

The dynamics and diversity of the microbial populations of $\mathrm{QPB}$ was characterized by DGGE of PCR products derived from DNA extracted from samples. Lactococci, lactobacilli, and streptococci were the dominant components of the microbiota identified by DNA sequencing of the $16 \mathrm{~S}$ rRNA gene (de la Rosa-Alcaráz, 2013, 2015; Aldrete-Tapia et al., 2014).

\section{Queso Crema de Chiapas}

Queso Crema de Chiapas (QCC) is an artisanal product manufactured in the state of Chiapas in 3 different regions: North, Frailesca (center), and Costa (coast). The cheese's physical, chemical, and microbiological characteristics vary depending on the production region (Rangel-Ortega, 2011; Villegas de Gante et al., 2011). Its flavor is acidic and its paste is fresh, soft, and pressed. This type of cheese is obtained through a prolonged acid-enzymatic coagulation of cow raw milk and has unique sensory characteristics due to the endogenous LAB in milk from this region (CervantesEscoto et al., 2008; Villegas de Gante et al., 2011). Cheese making starts with milk maturation for 3 to 5 $\mathrm{h}$ at ambient temperature $\left(\geq 25^{\circ} \mathrm{C}\right)$ so that the natural microflora multiplies; then, rennet is added and coagulation takes place over approximately 2 to $8 \mathrm{~h}$ so that a highly acidic curd is produced. Then, the curd is cut and left undisturbed overnight. The following day, curds are placed in cotton bags that are hanged for whey draining. At the end of this draining period, curds reach a $\mathrm{pH}$ of 4.5 and are ready for kneading, salting, molding, and pressing in a rustic wooden or metallic press (Figure 7). It is marketed in rectangular pieces covered with a 3-layer package: plastic film, aluminum foil, and yellow or red cellophane.

There are more than 600 small dairies in this region, and cheesemaking is one of the main economic activities. Queso Crema de Chiapas is one of the Mexican artisanal cheeses with a collective mark and has potential for obtaining a PDO (Villegas de Gante et al., 2011). Because this type of cheese has unique sensorial characteristics due to the endogenous LAB, the dynamics of the microbial consortia of LAB present in QCC were characterized by DGGE of PCR products derived from DNA extracted from cheese after 15 and $30 \mathrm{~d}$ of ripening (Rangel-Ortega, 2011; Rangel-Ortega et al., 2012). The dominant genera were Lactobacillus, Streptococcus, and Lactococcus, as identified by DNA sequencing of the $16 \mathrm{~S}$ rRNA gene. The population dynamics of LAB in QCC were different in structure and diversity according to season and region as determined by DGGE; on the other hand, they were similar regardless of the maturity stage. These results may be useful in the production of starter cultures for the manufacture of QCC (Rangel-Ortega, 2011; Rangel-Ortega et al., 2012).

\section{Queso Cotija}

Queso Cotija is an artisanal cheese found in a wide variety of forms. It is hard and pressed into a cylindrical shape that can weigh up to $22 \mathrm{~kg}$. Although its name is linked to the town of Cotija, Michoacan, traditional production of this cheese is concentrated in a small region located along the eastern mountain range of Sierra de Jalmich in Mexico, between the states of Jalisco and Michoacan. However, similar versions are produced under different conditions and using distinct manufacturing processes, mainly in the states of Jalisco, Michoacan, Veracruz, and Chiapas, where they are generally considered to be imitation cheeses.

In 2005, designation as a collective mark was sought after and achieved, with the goal of differentiating authentic Cotija cheese from its imitations. The cheese was therefore classified according to its official region of origin. Afterward, with the support of academic groups, its artisanal manufacture was regulated and standardized, which resulted in the creation and approval of a normative regulation, NMX-F-735-COFOCALEC-2011. To the date, regional Cotija cheese is the only cheese in Mexico for which its artisanal production

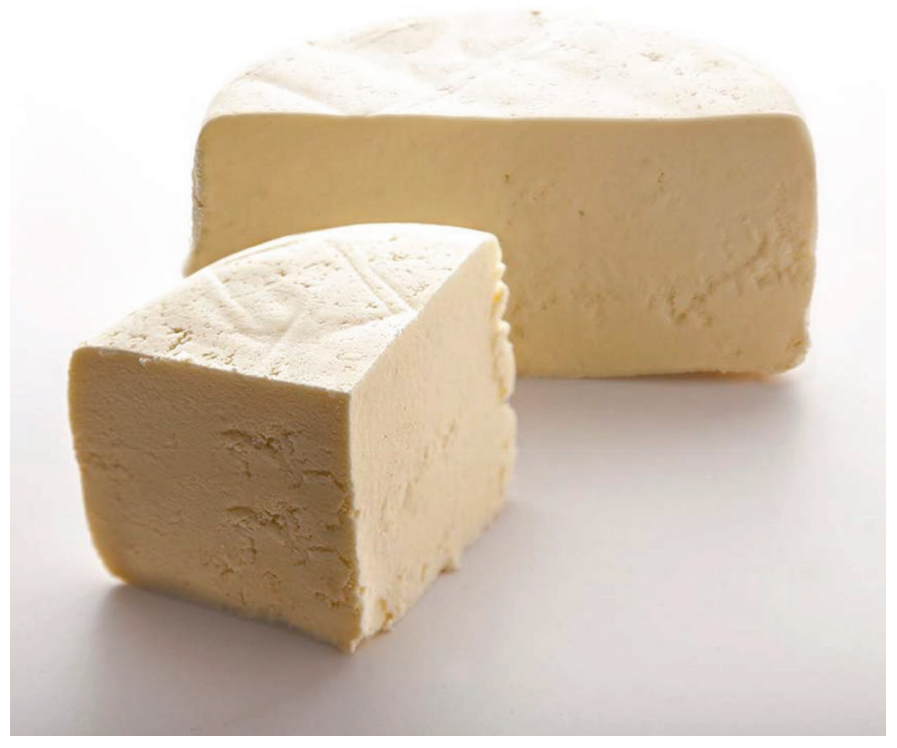

Figure 7. Artisanal Mexican queso Crema de Chiapas. 
is exclusively regulated by an official Mexican norm (COFOCALEC, 2011a).

The tradition surrounding the authentic production of Cotija cheese dates back more than $400 \mathrm{yr}$ to the Sierra de Jalmich region, specifically during the months of July to October. Cotija cheese is exclusively produced from mixed native-Zebu livestock. During its processing, the milk is acidified and curdled at a temperature of 27 to $30^{\circ} \mathrm{C}$ for 1 to $2 \mathrm{~h}$, using natural curdling agents. Once the curds achieve a certain consistency, they are cut, drained on fiber mats, and kneaded. Additional salt is added until a homogeneous mixture is achieved; then, it is placed in wooden, cylindrical molds that are fastened by belts or by twine from maguey fibers that are tied around the exterior of the mold, maintaining pressure for a period of 18 to $24 \mathrm{~h}$. Subsequently, the molds are placed under pressure for an additional 8 to $12 \mathrm{~d}$, until the cheese is completely drained. Finally, it is left to mature in the cheesemaking facility for a period of at least 3 mo (Figure 8; Poméon, 2007; ChomboMorales, 2008; Flores-Magallón et al., 2011).

The characteristic smell, texture, and taste of authentic Cotija cheese are favored by the environmental conditions surrounding its production, in addition to the type of milk that is used during production and its associated microbiota content. Such peculiarities make Cotija a unique Mexican cheese (Poméon, 2007; FloresMagallón et al., 2011).

\section{RAW MILK IN THE PRODUCTION OF ARTISANAL MEXICAN CHEESE}

Although the production of cheese is an important industry throughout the world, all cheesemaking begins with the selection of high-quality milk, considering its physical, chemical, and microbiological characteristics (Fox and McSweeney, 2004). Cheese is produced by the fermentation of milk, a process that has historically depended upon the presence of microbiota in raw milk, including bacteria, fungi, and yeasts. The presence of microorganisms and their successional stages and interactions play an important role in the production of cheese, including the acidification of the milk curds and the formation of the cheese and its ripening that give rise to differences in texture, composition, smell, and flavor (Beresford et al., 2001; Ndoye et al., 2011; Mallet et al., 2012). Many cheesemakers add raw milk in the production process of cheese, because it is considered by many to be essential for achieving a good flavor, which is in large part a result of the proteolysis and lipolysis of the microbiota contained in raw milk (López and Mayo, 1997; Poznanski et al., 2004; Medina et al., 2011)

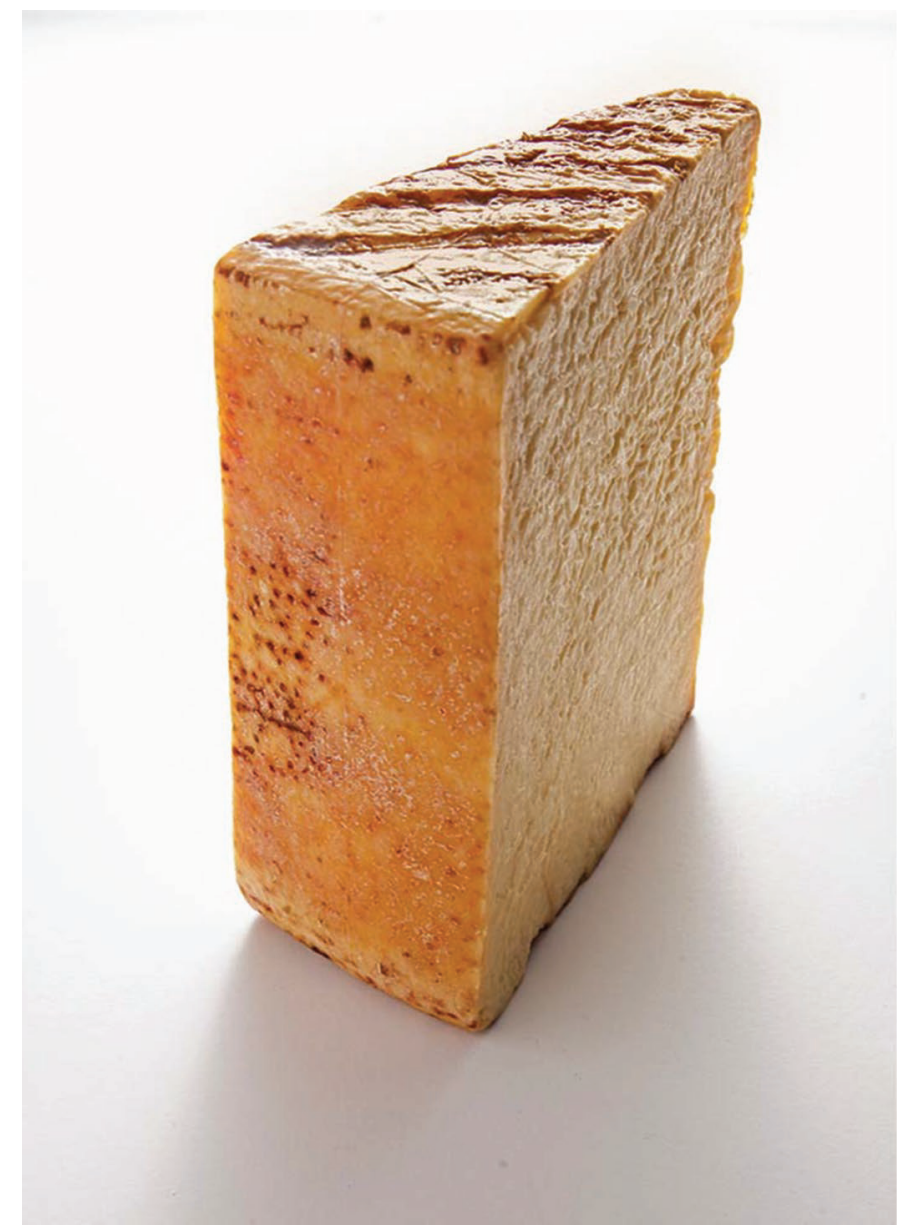

Figure 8. Artisanal Mexican queso Cotija.

Therefore, the native microbiota of raw milk is partially responsible for the distinctive smell, texture, and taste that only cheeses produced from raw milk can offer. A range of additional factors, such as the production environment, climate, and type of cattle feed (or free range/natural), also significantly influence the unique characteristics of the final cheese (Poznanski et al., 2004; Licitra, 2010).

However, artisanal cheeses may not be classified simply according to the use of raw milk in their production, because several practices are involved that influence their production and safety (Licitra, 2010). In spite of this knowledge, Mexican regulations concerning food safety promote the strategy of pasteurizing milk to guarantee the safety of dairy products to consumers, with the exception of cheeses aged $90 \mathrm{~d}$ or more. This has created interest among researchers for future studies on different artisanal Mexican cheese varieties and their safety by addressing milk pasteurization and aging. 
A review of foodborne illness outbreaks has shown in several cases that cheeses produced from raw milk do not present a greater risk than those produced from pasteurized milk (De Buyser et al., 2001; Licitra, 2010). This is because the thermal treatment of milk significantly contributes to the microbial safety of cheese. Inadequate pasteurization, the presence of contaminants during postprocessing, or cross-contamination, or a combination of these, are the main factors that contribute to cheese being contaminated by pathogenic bacteria (Little et al., 2008; Licitra, 2010). For example, one such case occurred with Mexican style cheese manufactured in the United States, which was associated with a foodborne illness outbreak resulting from post-process contamination (Jackson et al., 2011; CDC, 2013, 2014). Thus, cheeses produced from raw milk should not be considered to be lacking in safety on the mere basis of being produced from raw milk, as several practices are involved in their quality and safety.

\section{CONCLUSIONS}

The current review provides general information on the state of the art of Mexican cheesemaking, including an outline of the most commonly produced cheeses. Certain varieties of artisanal Mexican cheese, such as Bola de Ocosingo, Poro de Balancan, Crema de Chiapas, and regional Cotija cheeses, possess unique characteristics that make them potentially eligible to be protected as PDO products. This distinction could help to expand their frontiers and allow them to become better known and appreciated in other parts of the world. It is necessary for authorities, academics, and cheesemaking organizations to carry out more research so that artisanal cheeses may be systematically characterized to obtain information that would aid in the standardization of the production of different cheese varieties. With sufficient information, official Mexican regulations could be established that would encompass and regulate the manufacture of Mexican artisanal cheeses. Finally, as many Mexican artisanal cheeses are produced from raw milk, studies are required to show the role of the lactic acid bacteria and their antagonistic effect on pathogenic microorganisms during aging following cheese making.

\section{ACKNOWLEDGMENTS}

The authors are grateful for the technical support received from Maria del Carmen Estrada Montoya and Ricardo Reyes Diaz (both from Centro de Investigación en Alimentación y Desarrollo, A.C. Hermosillo, Sonora, Mexico). We thank the Sectorial Research Fund for Agriculture, Livestock, Aquaculture, Agro-biotechnology, and Genetic Resources (SAGARPA-CONACyT, Call for funding 2010-1, Mexico City, Mexico) for financing the following project: Improvement of the Productivity, Competitiveness, and Sustainability of the Milk Production Chain of Milk Livestock in Mexico. Sub-project 5.-Development Program for the Integration of Value along the Different Steps of the Production Chain: Strengthening Artisanal Cheesemaking through Technological Intervention in order to Assure the Quality, Safety, and Traceability of Mexican Cheeses. We also thank the Instituto Mexicano del Queso, A.C. (Mexico City, Mexico) for its support in funding the images taken by Fernando Gómez Carbajal (LaCarmela Fotografía de Oficio Gastronómico, Mexico City, Mexico) to illustrate this text and Allison Marie Jermain (Ali Marie Translation, Hesperia, CA) for editing and proofreading the manuscript.

\section{REFERENCES}

Aldrete-Tapia, A., M. C. Escobar-Ramírez, M. L. Tamplin, and M. Hernández-Iturriaga. 2014. High-throughput sequencing of microbial communities in Poro cheese, an artisanal Mexican cheese. Food Microbiol. 44:136-141.

Alejo-Martínez, K., M. Ortiz-Hernández, B. R. Recino-Metelín, N. González-Cortés, and R. Jiménez-Vera. 2015. Tiempo de maduración y perfil microbiológico del queso de poro artesanal. Rev. Iberoam. Cienc. 2:15-24.

Beresford, T. P., N. A. Fitzsimons, N. L. Brennan, and T. M. Cogan. 2001. Recent advances in cheese microbiology. Int. Dairy J. 11:259-274.

Caro, I., S. Soto, M. J. Franco, M. Meza-Nieto, R. H. Alfaro-Rodríguez, and J. Mateo. 2011. Composition, yield, and functionality of reduced-fat Oaxaca cheese: Effects of using skim milk or a dry milk protein concentrate. J. Dairy Sci. 94:580-588.

Caro, I., S. Soto, L. Fuentes, N. Gutiérrez-Méndez, B. García-Islas, K. E. Monroy-Gayosso, and J. Mateo. 2014. Compositional, functional and sensory characteristics of selected Mexican cheeses. Food Nutr. Sci. 5:366-375.

CDC (Centers for Disease Control and Prevention). 2013. Online foodborne disease outbreak database. Accessed Jan. 8, 2015. http:// wwwn.cds.gov/foodborneoutbreaks/.

CDC (Centers for Disease Control and Prevention). 2014. Multistate outbreak of listeriosis linked to Roos Foods dairy products. Accessed Jan. 9, 2016. http://www.cdc.gov/listeria/outbreaks/ cheese-02-14/index.html.

Cervantes-Escoto, F., A. Villegas de Gante, J. A. Cesín-Vargas, and A. Espinoza-Ortega. 2008. Los Quesos Mexicanos Genuinos. Patrimonio cultural que debe rescatarse. 1st ed. Mundi Prensa México, México City, Mexico.

Cesin-Vargas, A., F. Cervantes-Escoto, and A. Villegas de Gante. 2012. Producción industrial y artesanal de queso en México. Pages 51-72 in La leche y los quesos artesanales en México. F. CervantesEscoto and A. Villegas de Gante, ed. Miguel Ángel Porrúa, D. F. Mexico, México.

Chombo-Morales, P. 2008. El queso cotija región de origen un caso especial. Pages 149-177 in Los Quesos Mexicanos Genuinos. Patrimonio cultural que debe rescatarse. 1st ed. Mundi Prensa México, México City, Mexico.

COFOCALEC (Consejo para el Fomento de la Calidad de Leche y sus Derivados). 2011a. Norma Mexicana NMX-F-738-COFOCALEC-2011. Sistema Producto Leche-Alimento-Lácteo-Queso Chihuahua-Denominación, especificaciones y métodos de prueba. 
Accessed Jan. 8, 2016. http://www.cofocalec.org.mx/catalogo/ por_tema.

COFOCALEC (Consejo para el Fomento de la Calidad de Leche y sus Derivados). 2011b. Norma Mexicana NMX-F-735-COFOCALEC-2011. Sistema Producto Leche-Alimento-Lácteo-Alimento lácteo regional-Queso Cotija artesanal madurado-Denominación, especificaciones y métodos de prueba. Accessed Jan. 9, 2016. http://www.cofocalec.org.mx/catalogo/por_clave.

De Buyser, M., B. Dufour, M. Maire, and V. Lafarge. 2001. Implication of milk and milk products in food-borne diseases in France and in different industrialised countries. Int. J. Food Microbiol. $67: 1-17$.

de la Rosa-Alcaráz, M. A. 2013. Dinámica poblacional de la microbiota del queso de poro de Balancán durante su proceso de fabricación artesanal. MS Thesis. Centro de Investigación en Alimentación y Desarrollo, A.C., Hermosillo, Sonora, Mexico.

de la Rosa-Alcaráz, M. A., A. Hernandez-Mendoza, B. Vallejo-Cordoba, and A. F. González-Córdova. 2015. Diversity and evolution of the microbial populations during manufacture of Poro de Balancán, a Mexican artisanal cheese. FIL-IDF World Dairy Summit 2015, Vilnius, Lithuania. International Dairy Federation.

De Oca-Flores, E. M., O. A. Castelán-Ortega, J. G. Estrada-Flores, and A. Espinoza-Ortega. 2009. Oaxaca cheese: Manufacture process and physicochemical characteristics. Int. J. Dairy Technol. $62: 535-540$.

Domínguez-López, A., A. Villanueva-Carvajal, C. M. Arriaga-Jordán, and A. Espinoza-Ortega. 2011. Alimentos artesanales y tradicionales: El queso Oaxaca como un caso de estudio del centro de México. Estud. Soc. 19:166-193.

Flores-Magallón, R., A. A. Oliva-Hernández, and J. A. Narváez-Zapata. 2011. Characterization of microbial traits involved with the elaboration of the Cotija cheese. Food Sci. Biotechnol. 20:9971003.

Fox, P. F., and P. L. H. McSweeney. 2004. Cheese: An overview. Pages 1-18 in Cheese: Chemistry, Physics and Microbiology. No. 1: General Aspects. 3rd ed. Elsevier Academic Press, Oxford, UK.

Gamboa-Alvarado, J. G., D. Rojas-Almaraz, L. G. Ramón-Canul, and E. J. Ramírez-Rivera. 2013. Determination of the quality of cheese "Chihuahua" type: Sensory and physicochemical approaches. Emir. J. Food Agric. 25:409-417.

Guerra-Martínez, J. A., J. G. Montejano, and S. T. Martín-del-Campo. 2012. Evaluation of proteolytic and physicochemical changes during storage of fresh Panela cheese from Queretaro, Mexico and its impact in texture. CyTA-J. Food 10:296-305.

Harris, N. B., J. Payeur, D. Bravo, R. Osorio, T. Stuber, D. Farrell, D. Paulson, S. Treviso, A. Mikolon, and A. Rodriguez-Lainz. 2007. Recovery of Mycobacterium bovis from soft fresh cheese originating in Mexico. Appl. Environ. Microbiol. 73:1025-1028.

Hernández-Morales, C., A. Hernández-Montes, E. Aguirre-Mandujano, and A. V. De Gante. 2010. Physicochemical, microbiological, textural and sensory characterisation of Mexican Añejo cheese. Int. J. Dairy Technol. 63:552-560.

Higuera-Ciapara, I. 1986. Small-scale cheesemaking of Latin American cheeses. Cheesemaker's J. 23.4.

Jackson, K. A., M. Biggerstaff, M. Tobin-D'Angelo, D. Sweat, R. Klos, J. Nosari, O. Garrison, E. Boothe, L. Saathoff-Huber, L. Hainstock, and R. P. Fagan. 2011. Multistate outbreak of Listeria monocytogenes associated with Mexican-style cheese made from pasteurized milk among pregnant, Hispanic women. J. Food Prot. 74:949-953.

Jiménez-Guzmán, J., A. Flores-Nájera, A. E. Cruz-Guerrero, and M. García-Garibay. 2009. Use of an exopolysaccharide-producing strain of Streptococcus thermophilus in the manufacture of Mexican Panela cheese. Food Sci. Technol. (Campinas.) 42:1508-1512.

Licitra, G. 2010. Worldwide traditional cheeses: Banned for business? Dairy Sci. Technol. 90:357-374.

Linnan, M. J., L. Mascola, X. D. Lou, V. Goulet, S. May, C. Salminen, D. W. Hird, M. L. Yonekura, P. Hayes, R. Weaver, A. Audurier, B. D. Plikaytis, S. L. Fannin, A. Kleks, and C. V. Broome. 1988. Epidemic listeriosis associated with Mexican-style cheese. N. Engl. J. Med. 319:823-828.
Little, C. L., J. R. Rhoades, S. K. Sagoo, J. Harris, M. Greenwood, V. Mithani, K. Grant, and J. McLauchlin. 2008. Microbiological quality of retail cheeses made from raw, thermized or pasteurized milk in the UK. Food Microbiol. 25:304-312.

Lobato-Calleros, C., L. Ramos-Solis, A. Santos-Moreno, and M. Rodriguez-Huezo. 2006. Microstructure and texture of panela type cheese-like products: Use of low methoxyl pectin and canola oil as milk-fat substitutes. Rev. Mex. Ing. Quim. 1:71-79.

López, S., and B. Mayo. 1997. Identification and characterization of homofermentative mesophilic Lactobacillus strains isolated from artisan starter-free cheeses. Lett. Appl. Microbiol. 25:233-238.

MacDonald, P. D., R. E. Whitwam, J. D. Boggs, J. N. MacCormack, K. L. Anderson, J. W. Reardon, J. R. Saah, L. M. Graves, S. B. Hunter, and J. Sobel. 2005. Outbreak of listeriosis among Mexican immigrants as a result of consumption of illicitly produced Mexican-style cheese. Clin. Infect. Dis. 40:677-682.

Mallet, A., M. Guéguen, F. Kauffmann, C. Chesneau, A. Sesboué, and N. Desmasures. 2012. Quantitative and qualitative microbial analysis of raw milk reveals substantial diversity influenced by herd management practices. Int. Dairy J. 27:13-21.

Medina, R. B., R. Oliszewski, M. C. Abeijón Mukdsi, C. P. Van Nieuwenhove, and S. N. González. 2011. Sheep and goat's dairy products from South America: Microbiota and its metabolic activity. Small Rumin. Res. 101:84-91.

Morales-Celaya, M. F., C. Lobato-Calleros, J. Alvarez-Ramirez, and E. J. Vernon-Carter. 2012. Effect of milk pasteurization and acidification method on the chemical composition and microstructure of a Mexican pasta filata cheese. Food Sci. Technol. (Campinas.) 45:132-141.

Moreno-Enriquez, R. I., A. Garcia-Galaz, E. Acedo-Felix, H. Gonzalez-Rios, J. E. Call, J. B. Luchansky, and M. E. Diaz-Cinco. 2007. Prevalence, types, and geographical distribution of Listeria monocytogenes from a survey of retail queso fresco and associated cheese processing plants and dairy farms in Sonora, Mexico. J. Food Prot. 70:2596-2601.

NASS (National Agricultural Statistics Service). 2013. Dairy Products 2012 Summary. Accessed Jan. 8, 2016. http://usda01.library. cornell.edu/usda/current/DairProdSu/DairProdSu-04-29-2013. txt.

Ndoye, B., E. Rasolofo, G. LaPointe, and D. Roy. 2011. A review of the molecular approaches to investigate the diversity and activity of cheese microbiota. Dairy Sci. Technol. 91:495-524.

Ortiz-Estrada, A. M. 2014. Diversidad y dinámica de las poblaciones microbianas durante la manufactura y almacenamiento de queso Chihuahua. MS Thesis. Centro de Investigación en Alimentación y Desarrollo, A.C., Hermosillo, Sonora, Mexico.

Paul, M., A. Nuñez, D. L. Van Hekken, and J. A. Renye. 2012. Sensory and protein profiles of Mexican Chihuahua cheese. J. Food Sci. Technol. 51:3432-3438.

Poméon, T. 2007. El Queso Cotija, México. Un producto con marca colectiva queso "Cotija Región de origen", en proceso de adquisición de una Denominación de Origen. FAO/IICA. San Salvador, México.

Pomeón, T., and F. Cervantes-Escoto. 2012. El sector lechero y quesero en México en las últimas décadas. Pages 7-41 in La Leche y los Quesos Artesanales en México. F. Cervantes-Escoto and A. Villegas de Gante, ed. Miguel Ángel Porrúa, D. F., México.

Poznanski, E., A. Cavazza, F. Cappa, and P. S. Cocconcelli. 2004. Indigenous raw milk microbiota influences the bacterial development in traditional cheese from an alpine natural park. Int. J. Food Microbiol. 92:141-151.

Rangel-Ortega, S. C. 2011. Identificación y Caracterización de los consorcios microbianos del queso crema tropical. MS Thesis. Centro de Investigación en Alimentación y Desarrollo, A.C., Hermosillo, Sonora, Mexico.

Rangel-Ortega, S. C., D. Ercolini, A. F. González-Córdova, and B. Vallejo-Cordoba. 2012. Identification and characterization of lactic acid bacteria in Crema Tropical Cheese through DGGE. Abstract number 132-02 in 12-IFT Annual Meeting and Expo, New Orleans, LA. Institute of Food Technologists, Chicago, IL. 
Renye, J. A., G. A. Somkuti, D. L. Van Hekken, and V. M. GuerreroPrieto. 2011. Short communication: Characterization of microflora in Mexican Chihuahua cheese. J. Dairy Sci. 94:3311-3315.

Rodriguez-Nogales, J. M., and F. Vázquez. 2007. Application of electrophoretic and chemometric analysis to predict the bovine, ovine and caprine milk percentages in Panela cheese, an unripened cheese. Food Contr. 18:580-586.

Romero-Castillo, P. A., G. Leyva-Ruelas, J. G. Cruz-Castillo, and A. Santos-Moreno. 2009. Evaluación de la calidad sanitaria de quesos crema tropical mexicano de la región de Tonalá, Chiapas. Rev. Mex. Ing. Quím. 8:111-119.

Saxer, S., S. M. Schwenninger, and C. Lacroix. 2013. Characterization of the microflora of industrial Mexican cheeses produced without added chemical preservatives. Food Sci. Technol. (Campinas.) 53:314-320.

SIAP (Servicio de Información Agroalimentaria y Pesquera). 2013. Boletin de la leche enero-marzo de 2013. Accessed Jan. 9, 2016. http://infosiap.siap.gob.mx/index.php?option=com_content\&vie $\mathrm{w}=$ article $\& \mathrm{id}=51 \&$ Itemid $=381$.

Solano-López, C., and H. Hernández-Sánchez. 2000. Behaviour of Listeria monocytogenes during the manufacture and ripening of Manchego and Chihuahua Mexican cheeses. Int. J. Food Microbiol. 62:149-153.

Solís-Méndez, A. D., J. G. Estrada-Flores, and O. A. Castelán-Ortega. 2013. A study on the texture diversity of the artisan Ranchero cheese from central Mexico. Int. J. Dairy Technol. 66:37-44.

Soto-Beltran, M., K. D. Mena, C. P. Gerba, P. M. Tarwater, K. Reynolds, and C. Chaidez. 2013. Risk Assessment of Listeria monocytogenes in Queso Fresco in Culiacan, Mexico. J. Microbiol. Res. $3: 111-116$.

SSA (Secretaria de Salud). 2010. Norma Oficial Mexicana NOM243-SSA1-2010, Productos y servicios. Leche, fórmula láctea, producto lácteo combinado y derivados lácteos. Disposiciones y especificaciones sanitarias. Métodos de prueba. Accessed Jan. 9, 2016. http://dof.gob.mx/nota_detalle.php?codigo $=5160755 \&$ fec ha $=27 / 09 / 2010$

Torres, N., and R. C. Chandan. 1981. Latin American white cheese-A review. J. Dairy Sci. 64:552-557.

Torres-Llanez, M., B. Vallejo-Cordoba, M. Díaz-Cinco, M. MazorraManzano, and A. González-Córdova. 2006. Characterization of the natural microflora of artisanal Mexican Fresco cheese. Food Contr. 17:683-690.

Torres-Vitela, M. R., M. Mendoza-Bernardo, J. Castro-Rosas, C. A. Gomez-Aldapa, L. E. Garay-Martinez, V. Navarro-Hidalgo, and A. Villarruel-López. 2012. Incidence of Salmonella, Listeria monocytogenes, Escherichia coli O157: H7, and staphylococcal enterotoxin in two types of Mexican fresh cheeses. J. Food Prot. 75:79-84.
Tunick, M. H., D. L. Van Hekken, J. Call, F. J. Molina-Corral, and A. A. Gardea. 2007. Queso Chihuahua: Effects of seasonality of cheesemilk on rheology. Int. J. Dairy Technol. 60:13-21.

Van Hekken, D. L., M. A. Drake, F. J. M. Corral, V. M. Guerrero-Prieto, and A. A. Gardea. 2006. Mexican Chihuahua cheese: Sensory profiles of young cheese. J. Dairy Sci. 89:3729-3738.

Van Hekken, D. L., M. A. Drake, M. H. Tunick, V. M. Guerrero, F. J. Molina-Corral, and A. A. Gardea. 2008. Effect of pasteurization and season on the sensorial and rheological traits of Mexican Chihuahua cheese. Dairy Sci. Technol. 88:525-536.

Van Hekken, D. L., and N. Y. Farkye. 2003. Hispanic cheeses: The quest for queso. Food Technol. 57:32-38.

Van Hekken, D. L., M. H. Tunick, L. N. Leggett, and P. M. Tomasula. 2012. Impact of curd milling on the chemical, functional, and rheological properties of starter-free Queso Fresco. J. Dairy Sci 95:5527-5535.

Van Hekken, D. L., M. H. Tunick, P. M. Tomasula, F. J. M. Corral, and A. A. Gardea. 2007. Mexican Queso Chihuahua: Rheology of fresh cheese. Int. J. Dairy Technol. 60:5-12.

Villanueva-Carvajal, A., M. Esteban-Chávez, A. Espinoza-Ortega, C. M. Arriaga-Jordán, and A. Dominguez-Lopez. 2012. Oaxaca cheese: Flavour, texture and their interaction in a Mexican traditional pasta filata type cheese. CyTA-J. Food 10:63-70.

Villegas de Gante, A. 2012. Los quesos Méxicanos genuinos (Necesidad de su rescate y valorización). Pages 123-132 in La Leche y los Quesos Artesanales en México. F. Cervantes-Escoto and A. Villegas de Gante, ed. Miguel Ángel Porrúa, D.F., México.

Villegas de Gante, A., and F. Cervantes-Escoto. 2011. La genuinidad y tipicidad en la revalorización de los quesos artesanales mexicanos. Estud. Soc. 19:146-164.

Villegas de Gante, A., F. Cervantes-Escoto, A. Cesín-Vargas, A. Espinoza-Ortega, A. Hernández-Montes, A. Santos-Moreno, and A. R. Martínez-Campos. 2014. Atlas de los Quesos Mexicanos Genuinos. Ed. Biblioteca Básica de Agricultura, Texcoco, Estado de México.

Villegas de Gante, A., A. Santos-Moreno, and A. Hernández-Montes. 2011. Caracterización del queso crema de Chiapas (Aspectos socioeconómicos y tipicidad del producto). Ed. Universidad Autónoma de Chapingo. México-Texcoco. Edo. de México, México.

Yescas, C. 2009. Cheese of the Week: Queso de Bola de Ocosingo Accessed Jan. 8, 2016. http://lactography.blogspot.mx/2009/11/ cheese-of-week-queso-de-bola-de.html.

Yescas, C. 2012. Fromagge, Cheese, Fromagge, Cheese, Queso. Accessed Jan. 9, 2016. http://www.letraslibres.com/blogs/fromage-cheesequeso. 